\title{
A Discourse Analysis on Outdoor Advertising about Real Estate from the Perspective of Eco-linguistics
}

\author{
Maoqun Zhang \\ School of Foreign Languages \\ Wuhan University of Technology, WHUT \\ Wuhan, China
}

\begin{abstract}
Eco-linguistics is an interdisciplinary which combines ecology and linguistics. It focuses on the study of language ecology and investigates the relationship between language and ecology, which reflects the idea of returning language to the natural ecology. The birth of eco-linguistics not only helps to establish a new type of relationship between mankind and the natural environment, but also helps to improve the value of linguistics itself. In recent years, ecolinguistics has been highly valued by many linguists at home and abroad. They think that eco-linguistics, especially ecodiscourse analysis, must pay attention to the ecological philosophy that analysts should have ecological concept. Under the guidance of ecological philosophy and green grammar, this essay will analyze the ecocriticism of real estate outdoor advertisement discourse. Besides, it will describe the relationship between real estate advertisement and language environment. What's more, it will reveal the ecological development road of the real estate outdoor advertising language. Finally, it will help consumers sensibly accept real estate outdoor advertising contents.
\end{abstract}

Keywords-eco-linguistics; ecosophy; green grammar; real estate outdoor advertising

\section{INTRODUCTION}

With the rapid development of the global economy, human beings are doing everything they can to create wealth for themselves. The natural environment of the world has been severely damaged. The ecological crisis is everywhere, and human survival is greatly threatened. The root cause of such situations is the "anthropocentric" values that human beings see themselves as the center of the universe. In order to change this traditional value and establish the "ecocentrism" consciousness, domestic and foreign linguists have put forward "ecological philosophy" and "ecologists" from the perspective of ecological linguistics in an attempt to transform people's values or ideology. Huang Guowen and Chen Yang, famous scholars in China, hold that eco-linguists should "think and act eco-linguistically." Huang Guowen thinks that the dichotomy between man and nature in western philos ophy tradition neglects the effects of human behaviors on the environment, thus he proposes that the research of eco-linguistics in Chinese context should follow the ecosophy and ecological wisdom in ancient China, such as "oneness of man and nature", "conform to nature" and "inactivity". This thesis randomly selects 20 pieces of real estate advertising in Chutian City Newspaper, then conducts ecocritical discourse analys is of these ads under the guidance of eco-linguistics. This thes is tends to reveal the phenomenon of surface ecologization in these ads points the potential development directions for real estate ads and serves to improve people's recognition capability of nonecological phenomenon in this kind of discourse.

\section{THEORETICAL FRAMEWORK}

\section{A. Ecological Philosophy}

Huang Guowen and other scholars agree to the ideas proposed by Alexander and Stibbe (2014): when scholars analyze the discourse related to ecological issue, they need to analyze all types of discourse in ecological way according to ecological concepts and principles, which is called "ecological analys is of discourse". Huang Guowen in 2016 states when scholars analyze discourses in ecological way, they need to pay attention to their own "ecological view" which is also called ecological philosophy or ecosophy. The ecological analysis of discourse and the construction of utterances to events in the world show the role of language researchers in the development of human society and their responsibilities to society (Huang Guowen, 2016).

Huang Guowen demonstrates that eco-linguists' world view, methodology and ecological imperative concept are particularly important for the research of eco-linguistics. In the process of ecological analysis of discourse, the world view and ecological ethic that we hold and the story of things and events have great influences on the analysis and evaluation of the objective world. Therefore, in the process of Ecological Discourse Analysis, we have to have the right ecological view.

\section{B. Green Grammar}

Halliday (1990) holds that green grammar is a lexical and grammatical way of expressing modern ecological ethics, which fully embodies the harmonious coexistence of man and nature and everything is equal. This grammar is against the idea of "anthropocentrism", "growthism" and "classism" and so on. It advocates that the world should be considered as an interconnected, interdependent and dynamic ecosystem. The green grammar of Halliday is embodied in the non- 
ecological criticis $m$ of the language system, namely, the three non-ecologicalideas in the critical language system.

Based on green grammar, ecological analysis of discourse mainly investigates the following three aspects: (1). How are ecological environment problems in language constructed and organized, which makes these problems difficult to solve? (2). what are non-ecological factors in English language system? (3). How should we make grammar and language system more ecological, that is, how should deal with the non-ecological factors in grammar and language system?

\section{NON-ECOLOGICAL DiSCOURSE ANALYSIS OF REAL EST ATE OUTDOOR ADVERTISING}

In twentieth Century, there was a serious language ecological crisis in language, such as the endangered language, the distinction of a certain language, the sharp decline of language diversity. There was "ecological turn" in the study of linguistics, and ecological linguistics came into being. Eco-linguistics focuses on the interaction between language and ecology: (1) Ecological problems within the language itself. (2) the influence of language on ecology. Based on the three non-ecological thought-anthropocentrism, classism and growthism, this paper will do research on the non-ecological factors of the real estate outdoor advertising language system (vocabulary and grammar) and criticize on the non-ecological factors of the real estate outdoor advertising language system. Then the paper will appeal to the real estate agents for ecological reform. So the green grammar can be better built in this discourse.

\section{A. Anthropocentrism}

Fill (2001) points out that anthropocentrism refers to the phenomenon that people always look at everything from the angle whether it is useful to themselves. Larson (2011) argues that in dealing with ecological issues, we should not only pay attention to the problems caused by "anthropocentrism" but also pay attention to the important role of mankind in ecological issues.

- Example 1: “伟大的城市, 有我的梦想。” ( Great city, My dream. )

- From grammatical level, “城市里有 “我” 的梦想。” (My dream lies in the city.) After further analysis, we find that the later emphasizes on the subjectivity of human being, which is the typical example of "selfcenter". That is to say, real estate agents focus on "human being", not what "human" can do for the ecological environment of the city.

- Example 2: “听湖而居, 一生所愿。” (Live by the lake -you always longed for. )

- At the semantic level, “能住在湖边享受大自然是“一个 人, 一生的愿望。” (Living by the lake and enjoying the nice nature is the lifelong dream of 'human'. ) Similarly, when designing the advertising, agents consider only the "human" inside, not the relationship between "human" and "environment". Besides, for satisfying their own interests, agents will not show the specific real estate information on the advertising, which may mislead and cheat the customers.

\section{B. Classism}

Material process refers to the process of doing something which involves two participants: act and goal. This kind of sentence pattern divides the world into human and nonhuman, thoughtful and thoughtless species. Some species cannot make sound to defend themselves, but it doesn't mean that they should become the victims of human desires.

Example 3: “独占澴河, 公园美宅。” (Monopolize the Huan River, enjoy the beauty of the garden house.)

The "actor" of "monopolize"(live solely) is "human", obviously, "human" has consciousness and thoughts. However, the target or goal of "being monopolized" (the Huan River) is non-human and unconsciousness. What's more, the word "monopolize"(live solely) gives people an impression of "supremacy", that is, "human" is superior to "nature".

Example 4: “新洪山, 百年学府公馆。” (New Hongshan, Centennial College mansion.)

From the sentence, we can easily obtain the information that the specific location of this mansion lies in "new Hongshan" with historic university nearby. At first sight, this sentence is grammatically correct, but through further analysis, we find that "institution" symbolizes "identity", that is to say, "institution" gives people a feeling of prestige compared to other houses. Therefore, real estate agents would like to put "institution" into the advertising to cater to customers' buying psychology and need.

\section{Growthism}

Growthis m means that the growth is good, and the more growth, the better. Comparative and superlative are the concentrated expression of growthis $\mathrm{m}$. In normal conditions, people think that more is better than less, big is better than small and growth is better than reduce. However, people have this sort of awareness at the cost of resource consumption and environmental destruction.

- Example 5: “醇熟现楼, 抢先入驻。” (There is a completed house that you can buy it as soon as possible.)

- With the rapid development of Chinese economy, real estate industry constantly springs up. At the same time, real estate advertising emerges increasingly into people's sights. “熟”, “现” (completed and accomplished) represent the house has already been completed. Compared to “未熟” (uncompleted) house, the house built already has great advantage over uncompleted house. This kind of advertising reminds customers rushing to buy these completed houses.

- Example 6: “住的要顶好! No.1!” (Live the best! No.1! ) 
- "The best", "No.1" is the suggestion of superlative degree: Buy the best. Real estate agents make use of exaggerated means to attract the attention of consumers and cater to their buying psychology. The implication of this advertising is that this real estate is the best. However, this type of real estate is at the cost of resource consumption and environmental damage, thus real estate agents should pay attention to the application of ecological language in the promotion or sale of such real estate. What's more, they also need to call on buyers pay attention to ecological protection and improve the environmental awareness of buyers.

\section{CONCLUSION}

This paper, under the guidance of ecological philosophy and green grammar, analyzes and criticizes the discourse of 20 real estate advertisements in Chutian Metropolis Daily. This paper argues that most contemporary real estate advertisements are non-ecological. They place undue emphasis on "Anthropocentrism "" Classism "and" Growthism ", but neglect the relationship between man and nature, that is, the lack of ecological philosophy. In response to these phenomena, this paper attempts to guide real estate agents to pay more attention to the ecology of real estate advertising discourse. This paper thinks that real estate agents should keep balance between economic benefits and social benefits. At present, linguists think that it is impossible and unrealistic to give up the thought of "anthropocentric" to accept the idea of "ecocentric".

Under such social background, eco-linguis ts should guide the development of the real estate outdoor advertising to the direction of "ecocentric". Meanwhile, they also need to guide the advertising marketing strategy to meet the value orientation of Chinese people. For examp le, "Celestial voices, gentleman renewing strengths" in Zhou Yi a Chinese fa mous philosophical book. The striving spirit of "renewing strength" is the reflection of modern people's efforts for self-improvement and endless fighting for happy life. Besides, it is the most influential aspect of Confucianism in modern business spirit.

\section{REFERENCES}

[1] G. W. Huang and Y. Chen, "Ecosophy and ecological analysis of discourse," Foreign Language and Literature( bimonthly). China, Vol.32, pp. 55-60, Dec 2016.

[2] W. J. Zhou, "The concept and practice of ecological linguistics in Chinese context-a review of Huang Guowen's study on ecolinguistics," Journal of Xi'an International Studies University, vol. 25. Sept. 2017.

[3] M. A. K, Halliday. "New ways of meaning: The challenge to applied linguistics" [J]. Journal of Applied Linguistics, 1990,(6).

[4] R, Alexander, \& A. Stibbe. "From the analysis of ecological discourse to the ecological analysis of discourse" $[\mathrm{J}]$. Language Sciences ( 41): 104-110. 2014.

[5] B. Larson, Met aphors for environmental sust ainability: redefining our relationship with nat ure[M]. New Haven, CT: Yale University Press. 2011. 